\title{
HUBUNGAN ASUPAN ENERGI, PROTEIN, ZAT BESI DAN AKTIVITAS FISIK DENGAN KADAR HEMOGLOBIN TENAGA KERJA WANITA DI PABRIK PENGOLAHAN RAMBUT PT. WON JIN INDONESIA
}

\author{
Anggi Irna Mantika, Tatik Mulyati*) \\ Program Studi Ilmu Gizi Fakultas Kedokteran Universitas Diponegoro \\ J1.Dr.Sutomo No.18, Semarang, Telp (024) 8453708, Email : gizifk@ undip.ac.id
}

\begin{abstract}
Background: Anemia is a major health problem related to the nutrients that occur in women labour. The causative factors of anemia in women labour is a less nutrition intake, menstruation every month, and heavy physical activities. Nutritional substances considered with heamoglobin level are energy intake, protein and iron. According to data of Department of manpower, Transmigration and social Purbalingga in 2014 state that 72,5\% of labour was women. PT Won Jin Indonesia is located in Purbalingga with 260 labour, 89\% of labour was women. There;s 405 labour absent in April, Mei and Juni 2014.

Methods: The study was axplanatory using cross sectional study. The subject were 74 women labour which was take by consecutive sampling. Heamoglobin level was measured by cyanmethemoglobin method. The energy and protein intake were obtain by 24-hour recall method during 3 days, the iron intake was obtain by Semi Quantitative Food Frequency. Physical activity taken by filling the form of physical activity. Normality of data analysis was analysed by Kolmogorov-smirnov. Data were analysed by correlation test Spearman rank.

Results: studies shown $85,1 \%$ have a good energy intake, 50\% have a good protein intake and $62.2 \%$ have a good iron intake. $52.7 \%$ have active physical activity. Levels of hemoglobin at $87.8 \%$ research categorised subject to normal (12-14gr/dl). Bivariat analysis shown that energy intake $(r=0,418)$, protein $(r=0,611)$, and iron $(r=0,547)$ had association with hemoglobin levels of labour women

Simpulan: Intake of energy, protein, and iron intake was associated with haemoglobin levels on women labour.
\end{abstract}

Keywords: energy intake; protein intake; the intake of iron; the levels of physical activity; hemoglobin

\begin{abstract}
ABSTRAK
Latar Belakang: Anemia merupakan masalah kesehatan utama berkaitan dengan gizi yang terjadi pada tenaga kerja wanita. Faktor-faktor yang menyebabkan terjadinya anemia pada tenaga kerja wanita adalah asupan gizi (energi, protein dan zat besi) yang kurang, menstruasi setiap bulan, dan aktifitas fisik yang berat.Dinas Transmigrasi dan Sosial Kabupaten Purbalingga pada tahun 2014 menyatakan dari 43.628 tenaga kerja 72,5\% merupakan wanita. PT. Won Jin Indonesia merupakan pabrik yang berada di Kabupaten Purbalingga dengan jumlah tenaga kerja 260 orang, 89\% merupakan tenaga kerja wanita. Data tenaga kerja yang tidak masuk karena sakit pada tiga bulan terahir yaitu bulanApril, Mei dan Juni 2014 sebanyak 405 tenaga kerja.

Metode: Jenis penelitian observasional dengan desain cross sectional. Besar subjek yang digunakan adalah 74 orang yang diambil secara consecutive sampling. Kadar hemoglobin diukur dengan metode cyanmethemoglobin dengan alat spektofotometer dan secara semi otomatik menggunakan alat flawcytometri Asupan energi dan protein diperoleh melalui metode recall 24 jam yang dilakukan selama 3 hari, sedangkan asupan zat besi diperoleh melalui Food Frequency Semi Quantitative. Aktivitas fisik diperoleh melalui pengisian form aktivitas fisik. Analisis kenormalan data menggunakan uji Kolmogorov smirnov dan analisis hubungan menggunakan uji Spearman.

Hasil: Asupan energi 85,1\% terkategori baik, 50\% memiliki asupan protein baik dan 62,2\% asupan zat besi baik. 52,7\% aktivitas fisik aktif. Kadar hemoglobin pada subjek penelitian 87,8\% terkategori normal (12-14gr/dl). Ada hubungan antara asupan energi $(r=0,418)$, protein $(r=0,611)$, dan zat besi $(r=0,547)$ dengan kadar hemoglobin tenaga kerja wanita.
\end{abstract}

Simpulan: Ada hubungan antara asupan energi, protein dan besi dengan kadar hemoglobin dan tidak ada hubungan antara aktivitas fisik dengan kadar hemoglobin.

Kata Kunci: asupan energi; asupan protein; asupan zat besi; aktivitas fisik; kadar hemoglobin

\section{PENDAHULUAN}

Data Badan Pusat Statistik (BPS) menunjukkan bahwa jumlah tenaga kerja di Indonesia meningkat setiap tahunnya.Jumlah tenaga kerja tahun 2011 mencapai 117,37 juta di tahun 2012 meningkat menjadi 120,41 juta. ${ }^{1,2,3}$ Sebagian besar tenaga kerja bekerja terutama di bidang
Industri dan tidak hanya bertumpu pada kaum lakilaki. Data tahun 2011 menyebutkan bahwa jumlah tenaga kerja wanita 41,6 juta dan tahun 2012 meningkat menjadi 43,3 juta. ${ }^{4,5}$

Tenaga kerja wanita sangat rentan mengalami masalah kesehatan karena selain berperan sebagai ibu dalam keluarga juga berperan 
dalam karirnya. Wanita yang bekerja sebagian besar masih termasuk dalam usia produktif sehingga rentan mengalami masalah kesehatan. ${ }^{6}$ Anemia merupakan masalah kesehatan utama berkaitan dengan gizi yang terjadi pada tenaga kerja wanita.Penelitian observasional di PT. HM Sampoerna Kudus menunjukan bahwa 33,4\% tenaga kerja wanita mengalami anemia sedangkan prevalensi anemia pada wanita usia subur sendiri di Indonesia pada tahun 2008 mencapai 29,7\%.10

Faktor-faktor yang menyebabkan terjadinya anemia pada tenaga kerja wanita adalah asupan gizi yang kurang, menstruasi setiap bulan, dan aktifitas fisik yang berat, sedangkan faktor asupan zat gizi yang dianggap mempunyai peranan adalah asupan energi, protein, dan zat besi. ${ }^{11}$ Adanya ketidakseimbangan jumlah energi yang diasup dapat menyebabkan rendahnya asupan zat besi dan penyerapan zat besi menjadi kurang maksimal.Energi dihitung berdasarkan umur, berat badan, tinggi badan dan aktivitas fisiknya. ${ }^{7}$ Aktifitas fisik yang dilakukan pada tenaga kerjatermasuk dalam aktifitas sedang sampai berat. ${ }^{48}$ Tingginya aktivitas fisik dan terbatasnya waktu yang dimilikiuntuk mengkonsumsi makanan,menyebabkan asupan makanan menjadi kurang dan akan mempengaruhi asupan zat gizi dalam pembentukan hemoglobin sehingga hemoglobin tidak dapat diproduksi secara normal. ${ }^{10,46}$ Penelitian observasional pada 335 tenaga kerja wanita di PT. Agro Indomas Kalimantan Tengah menunjukkan bahwa semakin rendah asupan energi maka kadar hemoglobin darah pada pekerja wanita semakin rendah. ${ }^{13}$

Penurunan kadar hemoglobin, hematokrit, dan hitung eritrosit (red cell count) merupakan tanda terjadinya anemia. Kadar hemoglobin yang rendah sangat berpengaruh terhadap kemampuan darah menghantarkan $\mathrm{O}_{2}$ yang sangat dibutuhkan tubuh. ${ }^{7,9}$ Aktifitas yang berat akan meningkatkan kebutuhan oksigen dalam jaringan. Keadaan tersebut dapat diperburuk oleh kekurangan asupan zat gizi seperti protein, zink, zat besi, vitamin (B12, asam folat dan vitamin C).Gejala umum dari anemia adalah kelemahan tubuh, lesu, mudah lelah, pucat, pusing, penurunan konsentrasi, keringat dingin, mata berkunang-kunang dan penurunan daya tahan tubuh. Kadar hemoglobin normal dalam darah pada wanita dewasa adalah $12-16 \mathrm{gram} / \mathrm{dl}^{7}$

Sintesis hemoglobin memerlukan ketersediaan besi dan protein yang cukup dalam tubuh. ${ }^{7,8}$ Zat besi merupakan komponen utama pembentukan heme pada hemoglobin. ${ }^{9}$ Rendahnya asupan zat besi dalam makanan merupakan faktor utama yang dapat memicu terjadinya anemia defisiensi zat gizi. ${ }^{12}$ Zat besi terdapat pada makanan seperti daging, ikan dan unggas (heme iron) dan pada tumbuhan seperti sayur, buah dan biji-bijian (nonheme iron). Zat besi yang berasal dari heme lebih mudah diserap oleh tubuh dibandingkan non heme. ${ }^{10,12}$ Asupan zat besi yang tidak adekuat dapat menyebabkan simpanan zat besi dalam tubuh akan berkurang sehingga suplai zat besi di sumsum tulang untuk pembentukan hemoglobin menjadi tidak adekuat. Akibat yang ditimbulkan adalah jumlah eritrosit protoporfirin bebas meningkat, terjadilah produksi eritrosit mikrositik dan nilai hemoglobin turun. ${ }^{9}$ Menurut Angka Kecukupan Gizi (AKG) kebutuhan besi pada wanita dengan usia 19 - 49 tahun adalah $13 \mathrm{mg}$ per hari. ${ }^{11}$

Protein merupakan komponen utama pada globin yang berperan dalam transoprtasi dan penyimpanan zat besi selain itu dalam penyerapan zat besi di usus halus juga dibantu oleh Heme Carrier Protein (HCP1) ${ }^{9}$. Penelitian kohort di mnaUnited State pada 963.676 orangmenunjukkan semakin rendah asupan protein semakin rendah kadar hemoglobin. ${ }^{14}$ Dalam kondisi normal dibutuhkan 10 - $20 \%$ dari total energi. Penelitian observasional pada 64 wanita usia subur di Biringkanaya Makasar menyatakan bahwa asupan protein hewani memiliki hubungan yang signifikan dengan kadar hemoglobin. ${ }^{15}$

Menurut data Dinas Tenaga Kerja, Transmigrasi dan Sosial Kabupaten Purbalingga pada bulan Januari sampai Apriltahun 2014 menyatakan dari 43.628 tenaga kerja 31.633 merupakan wanita, atau $72,5 \%$ tenaga kerja di purbalingga merupakan wanita dan sampai saat ini belum pernah ada penelitian tentang anemia. ${ }^{16}$

Berdasarkan latar belakang tersebut peneliti ingin melihat hubungan antara asupan energi, protein, besi dan aktivitas fisik dengan kadar hemoglobin pada tenaga kerja wanita di PT. Won Jin Indonesia yang berada di Kabupaten Purbalingga.Jumlah tenaga kerja di PT Won Jin adalah 260 tenaga kerja 89\% merupakan tenaga kerja wanita. Data tenaga kerja yang tidak masuk karena sakit dalam tiga bulan terahir yaitubulan April, Mei dan Juni 2014 adalah 405 tenaga kerja, selain itu pada PT ini belum pernah dilakukan pemeriksaan kesehatan berkaitan dengan kadar $\mathrm{Hb}$.

\section{METODE}

Penelitian ini dilakukan pada bulan Juni sampai dengan Juli 2014 di PT. Won Jin Indonesia yang terletak di Kabupaten Purbalingga, Jawa Tengah.Jenis penelitian observasional dengan desain cross sectional. 
Populasi terjangkau dalam penelitian ini adalah tenaga kerja wanita usia subur. Besar subjekminimal adalah 71 orang dengan koreksi besar sampel sebanyak 7 orang, subjek yang digunakan dalam penelitian ini adalah 74 orang. Besar sampel dihitung dengan rumus perkiraan menggunakan estimasi proporsi suatu populasi dengan tingkat kemaknaan $\left(Z_{\alpha}\right) 95 \%$, Pengambilan subjek penelitian dilakukan dengan teknik consecutive sampling dengan kriteria inklusi, subjek berusia 20 - 39 tahun, tidak dalam keadaan sakit kronis atau dalam perawatan dokter, tidak sedang mengkonsumsi suplemen atau obat-obatan yang mempengaruhi kadar hemoglobin, bersedia mengisi formulir inform consent, tidak merokok, tidak dalam keadaan hamil atau menyusui pada saat penelitian berlangsung, tidak sedang mengalami nifas, menstruasi saat pengambilan darah.

Variabel dalam penelitian ini meliputi variabel bebas berupa asupan energi, protein, besi dan aktifvtas fisik, dan variabel terikat berupa kadar hemoglobin.

Asupan energi dan protein diperoleh melalui metode recall 24 jam yang dilakukan selama 3 hari, sedangkan asupan besi diperoleh melalui Food Frequency Semi Quantitativedan Status Gizi berdasarkan IMT dikategorikan menggunakan klasifikasi IMT menurut World Health Organization (WHO) 2005. Aktivitas fisik diperoleh melalui pengisian form aktivitas fisik untuk umumdiadaptasi dari Committee Refference Dietary Intake tahun 2005 dengan skor 1-1,39 termasuk dalam kategori sedentary, 1,4-1,59 low active, 1,6-1,89 aktif dan $\geq 1,9$ sangat aktif. Hasil food recall dan FFQ Semi Quantitatif kemudian diolah menggunakan program nutrisurvey, lalu dihitung rerata konsumsinya perhari, dibandingkan dengan AKG sesuai dengan usia dan aktivitas fisik diperoleh dengan pengisian form aktivitas fisik yang diberikan dalam 3 hari termasuk pada hari libur. Asupan dikategorikan kurang jika kurang dari $80 \%$, cukup jika $80 \%$ hingga $100 \%$, lebih jika lebih dari $100 \%$. Adapun angka kecukupan gizinya pada wanita dengan usia 19 - 29 tahun kebutuhan energinya adalah $2250 \mathrm{kkal}$, sedangkan pada wanita usia 30 - 39 tahun kebutuhan energinya dalah 2150 kkal; pada wanita 19-29 kebutuhan protein adalah 56 gram dan 30-39 tahun kebutuhan protein adalah 57 gram; $13 \mathrm{mg}$ besi.

Data kadar hemoglobin diperoleh dari hasil pengukuran dengan menggunakan metode cyanmethemoglobin dengan alat spektofotometer dan secara semi otomatik menggunakan alat flawcytometri. Pengambilan sampel darah dan pengukuran kadar hemoglobin dilakukan oleh tenaga analis kesehatan dari laboratorium kesehatan Dinas Kabupaten Purbalingga. Data kadar hemoglobin yang diperoleh dikategorikan menjadi normal dan kurang. Kadar hemoglobin pada wanita dikatakan kurang jika memiliki nilai dibawah 12 $\mathrm{mg} / \mathrm{dl}$.

Analisis statistik menggunakan program Statistical Package for Social Science (SPSS). Analisis univariat dilakukan untuk mendeskripsikan data karakteristik subjek, kadar hemoglobin, asupan energi, protein, besi dan aktivitas fisik. Data tersebut diuji kenormalannya menggunakan uji kolmogorov-smirnov. Analisis bivariat menggunakan uji korelasi Spearmen karenavariabel kadar hemoglobin, asupan energi, protein, besi dan aktivitas fisik berdistribusi tidak normal.

\section{HASIL PENELITIAN \\ Karakteristik Subjek}

Gambaran umum subjek dilihat berdasarkan umur, pendidikan dan status gizi ditunjukkan dalam tabel 1 .

Tabel 1.karakteristikberdasarkan umur, pendidikan, status gizi, dan aktivitas fisik

\begin{tabular}{lcc}
\hline Karakteristik & \multicolumn{3}{c}{ Tenaga Kerja Wanita } \\
\cline { 2 - 3 } & & $\%$ \\
\hline Umur & 39 & 52,7 \\
$21-29$ tahun & 35 & 47,3 \\
$30-39$ tahun & 74 & 100 \\
\hline Total & 9 & 12,2 \\
Pendidikan & 36 & 48,6 \\
SD & 29 & 39,2 \\
SMP & 74 & 100 \\
\hline SLTA & & \\
\hline
\end{tabular}




\begin{tabular}{lcc}
\hline Status Gizi & 3 & \\
Gizi kurang $<18,5$ & 28 & 4,1 \\
Normal 18,5-22,9 & 20 & 37,8 \\
Gemuk 23,0-24,9 & 12 & 27,1 \\
Obesitas I 25-29,9 & 11 & 16,2 \\
Obesitas II >30,0 & & 14,8 \\
& 74 & \\
\hline Total & & 100 \\
\hline Aktivitas Fisik & 35 & 47,3 \\
Low active & 39 & 52,7 \\
Aktif & 74 & 100 \\
\hline Total & & \\
\hline
\end{tabular}

Umur pada subjek penelitian merupakan usia subur yaituberkisar antara 21 sampai 39 tahun. Pendidikan yang dimiliki oleh subjek penelitian sebagian besar yaitu $48,6 \%$ berpendidikan SMP. Sebagian besar status gizi subjek memiliki IMT $\geq$ 23 atau sebanyak $58,1 \%$ terkategori gemuk, obese I dan obese II.Aktivitas fisik pada subjek penelitianmemiliki aktivitas fisik rendah $47,3 \%$ dan52,7\% aktivitas fisik aktif .

Asupan Energi, Protein dan Besi

Asupan energi, protein dan besi subjek penelitian ditunjukkan dalam tabel 2 .

Tabel 2.Asupan energi, protein dan zat besi

\begin{tabular}{lcccccc}
\hline \multirow{2}{*}{ Asupan zat gizi } & \multicolumn{7}{c}{ Kategori Asupan } \\
& \multicolumn{7}{c}{ Energi (kkal) } & \multicolumn{2}{c}{ Protein (gr) } & Besi (Fe) (mg) \\
\cline { 2 - 7 } & $\mathrm{n}$ & $\%$ & $\mathrm{n}$ & $\%$ & $\mathrm{n}$ & $\%$ \\
\cline { 2 - 7 } & 11 & 14,9 & 8 & 10,8 & 6 & 8,1 \\
Kurang (<80\%) & 63 & 85,1 & 37 & 50 & 46 & 62,2 \\
Baik (80-100\%) & 0 & 0 & 29 & 39,2 & 22 & 29,7 \\
Lebih (>100\%) & 74 & 100 & 74 & 100 & 74 & 100 \\
Jumlah Total & & & & & \\
\hline
\end{tabular}

Tabel 2 menunjukkan bahwa 85,1\% memiliki asupan energi yang baik. 50\% tenaga kerja memiliki asupan protein baik. Terdapat $62,2 \%$ tenaga kerja yang memiliki asupan besi baik.

\section{Kadar Hemoglobin Subjek}

Kadar hemoglobin pada subjek penelitian terkategori normal $87,8 \%$ dan $12,2 \%$ terkategori rendah ditunjukkan pada tabel 4 dibawah ini.

Tabel 4.Kadar hemoglobin subjek penelitian

\begin{tabular}{lcc}
\hline \multirow{2}{*}{ Kategori Kadar hemoglobin } & \multicolumn{3}{c}{ Tenaga Kerja Wanita } \\
\cline { 2 - 3 } & $\mathrm{n}$ & $\%$ \\
\hline Normal & 65 & 87.8 \\
Rendah & 9 & 12.2 \\
Total & 74 & 100 \\
\hline
\end{tabular}

Hubungan Asupan Energi, Protein, Besi dan Aktivitas Fisik dengan kadar Hemoglobin

Tabel 5.Rerata, standar deviasi, $r$, $p$ asupan energi, protein, zat besi dan aktivitas fisik

\begin{tabular}{lccc}
\hline Variabel & mean \pm SD & r & p \\
\hline Energi & $1860,97 \pm 121,133$ & 0,418 & 0,000 \\
Protein & $56,89 \pm 7,261$ & 0,611 & 0,000 \\
Zat Besi & $12,48 \pm 1,351$ & 0,547 & 0,000 \\
Aktivitas Fisik & $1,6099 \pm 0,02732$ & 0,067 & 0,653
\end{tabular}

Terdapat hubungan asupan energi dengan kadar hemoglobindengan nilai $\mathrm{r}=0,418$ kekuatan hubungan sedang.Adahubungan asupan protein dengan kadar hemoglobindengan nilai $r=0,611$ kekuatan hubungan terkategori kuat.Asupan besi dengan kadar hemoglobin menunjukkan ada 
hubungandengan nilai $\mathrm{r}=0,547$ kekuatan hubungan sedang, sedangkan pada aktivitas fisik dengan kadar hemoglobin tidak terdapat hubungan dengan nilai $\mathrm{p}>0,005$.

Hasil analisis multivariat menunjukkan bahwa asupan energi merupakan variabel yang paling berpengaruh terhadap kadar hemoglobin tenaga kerja wanita dengan nilai $\mathrm{p}=0,000$ dan nilai Adjusted $R$ square 0,500 dan koefisien 0,712 menunjukkan bahwa kadar hemoglobin dapat dijelaskan oleh asupan energi.

\section{PEMBAHASAN}

Subjek penelitian sebagian besar atau $52,7 \%$ berada pada usia $19-29$ tahundan semua subjek merupakan wanita usia subur. Wanita usia subur yang sedang mengalami menstruasi memiliki resiko yang lebih tinggi dibandingkan dengan wanita subur dengan keadaan tidak menstruasi. Volume darah yang keluar selama periode menstruasi normal berkiasar antara $25 \mathrm{ml}$ sampai dengan $60 \mathrm{ml}$. Pada konsentrasi hemoglobin normal volume darah mengandung sekitar 12 sampai $29 \mathrm{mg}$ besi sehingga mencerminkan pengeluaran darah ekuivalen dengan 0,4 sampai $1,0 \mathrm{mg}$ besi setiap harinya. Jumlah zat besi dari makanan yang terbatasdalam waktu yang lama dapat menyebabkan penurunan besi dari dalam darah. ${ }^{18,21}$

Pendidikan sebagian besar subjek adalah SMP 48,6\%. Pendidikan memiliki peran penting berkaitan dengan pengetahuan.Pengetahuan seseorang dapat diperoleh dari berbagai macam sumber, misalnya media masa, media elektronik, buku atau kerabat dekat.Pengetahuan dapat membentuk keyakinan tertentu sehingga seseorang berperilaku sesuai dengan keyakinan tersebut. Semakin tinggi pengetahuan gizi seseorang akan semakin memperhitungkan jenis dan jumlah makanan yang dipilih untuk dikonsumsi sehingga dapat mempengaruhi terhadap status gizi. ${ }^{22}$

Status gizi pada subjek sebanyak $58,1 \%$ memiliki status gizi lebih yaitu $27,1 \%$ overweight, $16,2 \%$ obese 1 dan $14,8 \%$ obese 2.Faktor yang dapat mempengaruhi status gizi meliputi faktor internal dan faktor ektrenal Faktor internal antara lain umur, jenis kelamin, infeksi, asupan zat gizi dan faktor ekstrenal meliputi pendidikan, pengetahuan, pekerjaan, aktivitas fisik, status ekonomi. ${ }^{22}$ Obesitasmenyebabkanterjadinya peningkatan sitokin pro-inflamator, khususnya IL-6 yang tinggi di dalam darah akan merangsang peroduksi regulator zat besi yaitu hepsidin. Hepsidin merupakan hormon yang terdiri dari 25 asam amino yang dihasilkan oleh hepar.Peningkatan produksi hepsidin yang berlangsung lama dapat menghambat penyerapan zat besi pada saluran cerna. ${ }^{25}$

Kadar hemoglobin pada sebagian besar subjek penelitian dalam kategori normal $87,8 \%$ subjek penelitian mempunyai kadar hemoglobin minimal 10,3 g/dl maksimal $15 \mathrm{~g} / \mathrm{dl}$ dengan nilai rerata 13,12 g/dl. Kadar hemoglobin pada wanita dikatakan kurang jika memiliki nilai dibawah $12 \mathrm{mg} / \mathrm{dlKadar}$ hemoglobin dapat dipengaruhi oleh asupan gizi yang baik, menstruasi setiap bulan, dan aktifitas fisik yang berat, sedangkan faktor asupan zat gizi yang dianggap mempunyai peranan adalah asupan energi, protein, dan zat besi. ${ }^{11}$ Adanya ketidakseimbangan jumlah energi yang diasup dapat menyebabkan rendahnya asupan zat besi dan penyerapan zat besi menjadi kurang maksimal.Energi dihitung berdasarkan umur, berat badan, tinggi badan dan aktivitas fisiknya. ${ }^{7}$ Tingginya aktivitas fisik dan terbatasnya waktu yang dimiliki untuk mengkonsumsi makanan,menyebabkan asupan makanan menjadi kurang dan akan mempengaruhi asupan zat gizi dalam pembentukan hemoglobin sehingga hemoglobin tidak dapat diproduksi secara normal. ${ }^{10,46}$

Sebagian besar subjek memliki asupan energi yang baik, data menunjukkan subjek dengan asupan energi baik adalah $85,1 \%$. Ada hubungan asupan energi dengan kadar hemoglobin, seperti yang dijelaskan dalam penelitian observasional yang dilakukan pada 335 tenaga kerja wanita di PT. Agro Indomas Kalimantan Tengah menunjukkan bahwa semakin rendah asupan energi maka kadar hemoglobin darah pada pekerja wanita semakin rendah. Kebutuhan energi dihitung berdasarkan umur, berat badan, tinggi badan dan aktivitas fisiknya. ${ }^{7}$.Kecukupan energi berdasarkan umur menurut AKG pada wanita dengan umur 19-29 tahun adalah 2250 kkal sedangkan pada wanita dengan usia 30 - 39 tahun adalah 2150 kkal. Tubuh membutuhkan energi untuk berlangsungnya proses fisiologis, seperti kontraksi otot, pembentukan dan penghantaran impuls saraf, sekresi kelenjar, dan berbagai reaksi sintesis dan degradasi selain itu energi juga diperlukan untuk melakukan berbagai pekerjaan tubuh salah satunya adalah kerja tubuh dalam metabolisme berbagai zat gizi. Apabila terjadi kekurangan energi baik secara kuantitatif maupun kualitatif, kapasitas kerja tubuh akan terganggu sehingga akan terjadi pembongkaran cadangan protein di dalam tubuh.Pemenuhan energi pada subjek didapatkan dari konsumsi makanan 3 kali sehari dari sumber makanan pokok, selingan dan lauk-pauk baik secara kualitas maupun kuantitas memenuhi kebutuhannya.Apabila subjek 
melakukan kerja lembur makan malam disediakan oleh pihak pabrik dengan komposisi yang memenuhi.

Subjek penelitianmemiliki asupan protein $50 \%$ terkategori baik dan secara statistik ada hubungan asupan protein dengan kadar hemoglobin, hal ini sejalan dengan penelitian observasional pada 64 wanita usia subur di Biringkanaya Makasar menyatakan bahwa asupan protein memiliki hubungan yang signifikan dengan kadar hemoglobin.Rerata protein yang diasup subjek penelitian adalah $56,89 \pm 7,261$ gram. Hal ini sudah sesuai dengan angka kecukupan gizi yang dianjurkan untuk umur 21 -39 tahun antara 56-57 gr per hari.Sumber protein yang dikonsumsi berasal dari sumber makanan hewani maupun nabati seperti daging, ayam, telur, ikan, dan dari sumber nabati tahu, tempe, kacang tanah, kacang kedelai ditambah dengan konsumsi 20 gr susu yang dilarutkan dalam air sebanyak 200 cc setiap pagi yang disediakan oleh pihak pabrik.

Protein merupakan makronutrien yang berperan dalam penyimpanan dan transportasi serta absorpsi zat besi. ${ }^{20}$ Salah satu tugas protein dalam tubuh adalah membantu besi non heme agar lebih mudah diabsorbsi dalam tubuh, gugus sulfur yang terdapat dalam protein mempunyai efek pemacu dimana gugus ini mengikat besi non heme dan membantu penyerapannya dalam tubuh asam amino ini terdapat dalam sumber makanan hewani. Asupan protein yang inadekuat dapat mengakibatkan gangguan pada metabolisme zat besi yang dapat mempengaruhi pembentukan hemoglobin, sehingga menyebabkan munculnya anemia. ${ }^{9}$

Data hasil penelitian menunjukkan terdapat $62,2 \%$ subjek memiliki asupan zat besi baik. Terdapat hubungan antara asupan zat besi dengan kadar hemoglobin.Asupanzatbesi didapatkan dari sumber makanan baik nabati maupun hewani. Sumber makanan nabati antara lain kacang-kacangan, tahu, dan tempe sedangkan makanan hewani antara lain daging, unggas, telur dan susu. Besi merupakan mineral yang sangat essensial.Bentuk besi non heme ada dalam bentuk yang teroksidasi (Fe 3+) sehingga biovailabilitasnya lebih rendah jika dibandingkan dengan besi heme, namun dengan mengonsumsi besi heme dengan non heme dalam waktu yang bersamaan dapat meningkatkan penyerapan besi non heme.Hal ini disebabkan besi heme mengandung meat factor yang dapat memacu absorpsi besi non-heme dari makanan. Penelitian yang dilakukan pada 64 wanita usia subur di Kecamatan Biringkanaya, Kabupaten Makasar Sulawesi Selatan menunjukkan bahwa terdapat hubungan yang signifikan antara frekuensi konsumsi besi non heme dengan kejadian anemia. Besi merupakan pembawa oksigen di hemoglobin dalam eritrosit dan myoglobin, jika terjadi kekurangan besi yang parah dapat menyebabkan anemia dengan beberapa gejala seperti kelelahan, jantung berdebar, dan tanda-tanda lain yang berkaitan dengan gangguan transportasi oksigen. ${ }^{17,19}$

Subjek penelitian sebagian besar memiliki aktivitas fisik aktif atau sedang yaitu sebanyak 52,7\% dengan skor antara1,59 - 1,69, aktivitas fisik seperti ini setara dengan membakar kalori sebanyak 170 - $240 \mathrm{kkal} / \mathrm{jam} .{ }^{23}$ Tidak terdapat hubungan antara aktivitas fisik dengan kadar hemoglobin. Aktivitas fisik yang dilakukan tenaga kerja saat bekerja sebagian besar adalah duduk untuk mengerjakan pekerjaannya yaitu membuat bulu mata dan selain aktivitas fisik lainnya yang dilakukan adalah bersepeda, dan melakukan pekerjaan rumah tangga.

Aktivitas fisik merupakan setiap gerakan tubuh yang dihasilkan oleh otot rangka yang memerlukan pengeluaran energi.Aktivitas fisik yang dapat mempengaruhi kadar hemoglobin adalah pada aktivitas fisik yang sifatnya berat.Aktivitas fisik yang terlalu berat dapat menimbulkan hematuria, hemolisis, dan perdarahan pada gastrointestinal yang dapat mempengaruhi status besi.Hematuria dapat terjadi karena adanya trauma pada glomerulus.Intensitas latihan dapat menyebabkan aliran darah pada ginjal menurun yang menyebabkan peningkatan laju filtrasi glomerulus.Hemolisis dapat timbul akibat dari kompresi pembuluh darah yang disebabkan oleh kontraksi yang kuat dari otot-otot yang terlibat dalam aktivitas fisik yang dilakukan. Hemolisis dapat menyebabkan kehilangan besi akibat penghancuran membran sel darah merah yang akan mempengaruhi kadar hemoglobin. ${ }^{20}$

\section{SIMPULAN}

Terdapat hubunganantara asupan energi, protein dan besi terhadap kadar hemoglobin pada tenaga kerja wanita di PT Won Jin Indonesia. Namun tidak terdapat hubungan antara aktivitas fisik dengan kadar hemoglobin.

\section{SARAN}

1. Perlu dilakukan edukasi gizi secara berkala untuk memepertahankan dan meningkatkan kadar hemoglobin dengan materi makanan gizi seimbang. 
2. Pemeriksaan kesehatan secara berkala perlu dilakukan untuk mengetahui kondisi kesehatan tenaga kerja.

3. Penelitian lebih lanjut perlu dilakukan mengingat ditemukan sebagian besar subjek penelitian memiliki status gizi lebih atau obesitas.

\section{DAFTAR PUSTAKA}

1. Badan Pusat Statistik. Keadaan Ketenagakerjaan Agustus 2011. Berita Resmi Statistik No. 74/11/Th. XIV, 7 November 2011

2. Badan Pusat Statistik. Keadaan Ketenagakerjaan Februari 2012. Berita Resmi Statistik No. 33/05/Th. XV, 7 Mei 2012

3. Badan Pusat Statistik. Keadaan Ketenagakerjaan Februari 2013. Berita Resmi Statistik No. 35/05/Th. XVI, 6 Mei 2013

4. Widiastuti S. Faktor Determinan Produktifitas Kerja Pada Tenaga Kerja Wanita. Semarang: Universitas Diponegoro; 2011

5. Badan Pusat Statistik. Perkembangan Beberapa Indikator Utama Sosial-Ekonomi Indonesia. 2012

6. Mallapiang Fatmawati, Nurfaddilah. Pelaksanaan Kesehatan dan Keselamatan Kerja Pada Tenaga Kerja Wanita di PT. Maruki Internasional Indonesia.Makasar : UIN Alaudin. 2013

7. Tracy Stopler. Medical Nutrition Therapy for Anemia. In: L. Kathleen M, Sylvia ES. Krause's Food, Nutrition, and Diet Therapy, $12^{\text {th }}$ Edition. USA : Saunders. 2008. 31:810.

8. Nelms Marcia, Suscher P. Ketryn, Lacey Karen, Roth Sara Long. Nutrition Theraphy and Pathophysisology 2/e. $2^{\text {nd }}$ ed. USA: Wadsworth Cengage Learning. 2010

9. Murray RK, Graner DK, Rodwell VW. Biokimia harper $27^{\text {th }}$ ed. Jakarta: EGC;2009.44:51

10. Ditjen Bina Gizi Masyarakat. Jaringan Informasi Pangan dan Gizi. Jakarta. 2008.

11. Menteri Kesehatan Republik Indonesia. Peraturan Menteri Kesehatan Republik Indonesia. Departemen Kesehatan;Jakarta.2013

12. Hunt JR. Bioavailability of Iron, Zink, and other trace minerals from vegetarian diets. Am J Clin Nutr 2003; 78 (suppl):633S-9S.

13. Suseno Widodo Harjo. Hubungan Antara Asupan Energi dan Status Gizi Terhadap Kadar Hemoglobin darah Tenaga Kerja Wanita di PT. Argo Indomas Kabupaten Seruyan Kalimantan tengah [Skripsi]. Semarang: Universitas Diponegoro. 2009

14. Thomson CA, Stanaway JD, Neuhosel LM, Snetselar LG, Stefanick ML, Andrell L, Chen Z. Nutrient Intake and Anemia Risk in The women's Health. Cancer Prev Res. 4(4);522-529, 2011.

15. Kurniati, Thaha A. Razak, Jafar Nurhaedar. Hubungan asupan zat gizi dengan kejadian anemia pada wanita prakonsepsi di kecamatan Bringkanaya Kota Makasar. Universitas Hasanudin. 2013.
16. Dinas Tenaga Kerja, Transmigrasi dan Sosial Kabupaten Purbalingga. Data Prusahaan di Kabupaten Purbalingga Tahun 2014..Purbalingga : Dinas Tenaga Kerja, Transmigrasi dan Sosial Kabupaten Purbalingga. 2014.

17. Widajanti L. Buku petunjuk praktikum survey konsumsi gizi. Semarang: Bagian Prodi Magister Gizi Masyarakat Program Pascasarjana UNDIP. 2007.

18. Gibson RS. Principle and Nutritional assesment. $2^{\text {nd }}$ ed. New York: Oxford University Press; 2005.p.446-9.

19. Hertanto WS. Hubungan antara status vitamin A dan seng ibu hamil dengan keberhasilan suplemen besi [disertasi]. Semarang: Universitas Diponegoro;2002

20. Gallagbar Margie Lee.Nutrition and Their Metabolism. In: Mahan LK, Stumps SE, editors. Krause's food, nutrition \& diet Therapy. $12^{\text {th }}$ ed. Philadelphia: Saunders;2008.p114-123.

21. Prastika Dewi andang. Hubungan lama menstruasi terhadap kadar hemoglobin pada remaja sisiwi SMA N 1 Wonosari [skripsi].Surakarta: Universitas Sebelas Maret.2011.

22. Kementrian Kesehatan Republik Indonesia. Pedoman Pencegahan dan Penanggulangan Kegemukan dan Obesitas. Jakarta: Kementrian Kesehatan RI.2012

23. Agoes, D dan Maria Poppy. 2003. Mencegah dan Mengatasi Kegemukan pada Balita. Jakarta: Puspa Swara.

24. Afrianti Dessy, Herry dan Ponpon. Perbandingan Besi Antara Perempuan Obes dengan Gizi Normal. Fakultas Kedokteran Universitas Pajajaran: RS Hasan Sadikin bandung. Vol. 14, No. 2. 2012.

25. Ganz T. Hepcidin and iron regulation, 10 years later. Blood.2011;117(17):4425-33. 